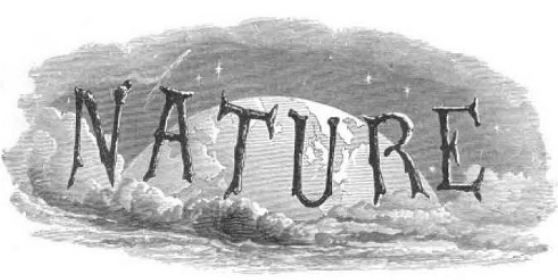

SATURDAY, SEPTEMBER 3, 1932

CONTENTS PAGE

The Contribution of Science to the Future

Mathematics and Astronomy of the Ancient Jewish

Rabbis. By S. B.

Pests of the Countryside.

Quantum Theory. By N. F. M.

Short Reviews

The Salle Pleyel, Paris, and Architectural Acoustics. By Prof. E. N. da C. Andrade
Quantitative Estimates of Sensory Events. By Dr. Allan Ferguson Obituary :

Mr. H. G. Watkins. By F. D. . . . . 336

News and Views . $\quad . \quad . \quad . \quad . \quad . \quad 337$

Letters to the Editor:

Photography of Penetrating Corpuscular Radiation.-P. M. S. Blackett and G. Occhialini

Intensity of Cosmic Radiation in the High Atmosphere.-Prof. E. Regener .

The $a$-Rays of Ionium.-Prof. Frederick Soddy, F.R.S.

The Glow in Photoelectric Cells.-The Right Hon. Lord Rayleigh, F.R.S.

Influence of Light on the Gorging of Culex pipiens L.-Dr. P. Tate and M. Vincent .

Bionomics of Trochus niloticus, Linn.-Dr. C. M. Yonge.

Prevention of Blight in Seed Potatoes.-T. Small

Sir Richard Threlfall and Sir Horace Darwin.Robert S. Whipple

A Possible Connexion between the Tiroposphere and the Kennelly-Heaviside Layer.-Prof. Ivo Ranzi

An Optically Active Inorganic Salt.-Dr. F. G.

Mann .

Dimensions of Fundamental Units. - Prof. William Cramp

Research Items

Astronomical Topics Solar Chromosphere. By E. A. M.

Resuscitation in Asphyxia

Cosmic Radiation

International Conference on Radio Communication

Calendar of Geographical Exploration

Societies and Academies .

Forthcoming Events

Official Publications Received .

SUPPLEMENT.

An Engineer's Outlook. By Sir Alfred Ewing, K.C.B., F.R.S., President of the British Associa-

Summaries of Addresses of Presidents of Sections

Editorial and Publishing Offices.

MACMILLAN \& CO., LTD.

ST. MARTIN'S STREET, LONDON, W.C. 2

Telephone Number: WHITEHALL 8831

Telegraphic Address: PHUSIS, LESQUARE, LONDON

Advertisements should be addressed to

T. G. Scott \& Son, Ltd., 63 Ludgate Hill, London, E.C.4

Telephone Number: City 1266

\section{The Contribution of Science to the Future}

T.HE return of the British Association to the 1 scene of its first meeting in 1831 cannot but suggest interesting comparisons between the position of science in 1831 and in 1932, and in this connexion it is not inappropriate that an engineer should occupy the presidential chair. A hundred years ago the nation was still in the throes of the industrial revolution and the economic depression which followed the Napoleonic wars. Discoveries and inventions in mechanical science had already found application in industry and were producing revolutionary changes in society. The whole structure of industry was being changed; old industries hitherto carried on in the homes were being swept into the mills and factories and new industries had been created. The railway and steamship age was just opening, and was indeed fostered by some of the researches promoted by the Association. Faraday had already made the fundamental discovery which later bore fruit in the dynamo and all the myriad ramifications of the electrical industries.

Much of the unrest of this period was due, however, to the indifference to the social or human consequences with which mechanical and other scientific discoveries had been applied in industry. At the time when the British Association held its first meeting at York, the human aspects of the industrial revolution were just beginning to receive attention, and the movement which a decade later led to the passing of the Factory Acts was then being initiated by Lord Shaftesbury. There is perhaps nothing upon which scientific workers, whether engineers or not, are entitled to look back with more justifiable pride than the steady rise in the ethical standards of the industrial community wherever science has influenced its activities. In 1831 it is fair to say that little trace could be found of the scientific spirit in industry. The discoveries of science had been applied to industry with as much indifference to science as to humanity. During the following century, however, science brought the spirit of service into competition with the desire for private gain, and the perversion of the gifts of science to the exploitation of those least able to look after themselves became less and less tolerable either to the industrial community or to society as a whole.

In this tendency, the tradition of science that the service of mankind should be given precedence over personal advancement has not been without influence, and in particular, engineers have played an important part in the permeation of

No. 3279, Vou. 130] 
industrial activities with the ideal of public service. The conception of the scientific spirit as involving the service of the community can be traced in the constitution of the Institution of Civil Engineers even in 1818, as well as in that of the Federated American Engineering Societies. This change in the ethics of industry has affected even economic theory, which has come to acknowledge that cooperation is a nobler ideal than self-interest; and indications could easily be multiplied to show that as industry becomes more widely influenced by science the obligation to subordinate self-seeking to the common good becomes more widely acknow. ledged.

The transformation in the ethics of a large section of industry would alone be sufficient to explain the attention directed at the present time to the social consequences of the new industrial revolution. This new industrial revolution has emerged from that of the early nineteenth century so gradually that it is only in the last few years that its fundamental characteristic has been clearly perceived--the substitution of other powers for human physical effort as the working energy of the world's production. The acute reaction on employment of the immense increase in the productive capacity of mankind made possible by science has at last brought us to see that science has given us to-day a new kind of production. Power production embodies a profound and vital change in the relation of human labour to the processes and products of the world's work. Not merely in industry but also in agriculture and in transport, not merely with regard to manual labour but also in regard to clerical work, those greater resources of power and fuller control over the forces of Nature are enabling man to do more with less effort. The mechanical invasion of mankind is still only in its initial stages. More and more the function of labour becomes that of admitting power to the machine and manipulating power controls. The intelligence and responsibility hitherto known as skill in craftsmanship are either displaced or concentrated in a small central staff of experts.

These two significant facts-that output in production has escaped from the limitations imposed by human physical energy, and that actual production to-day is indeed only a fraction of what it might be, if the existing plant were worked to full capacity-apart altogether from the prospect of further mechanisation in the office as well as in the works, have forced society to consider the economic and social consequences of the new forces placed in the hands of mankind. Scientific workers in particular must face those consequences and be increasingly concerned with the moral and social results of their work. The future of civilisation itself depends less upon the increasing powers which scientific discoveries and their application have placed in the hands of men than upon the way in which these powers are used.

The existence of world-wide unemployment and poverty, the sinister shrinking of international trade, side by side with this greater productive power, more abundant crops, and fuller control over Nature have suggested to many that the old objection of the manual worker to machinery is not without foundation. It is useless for the scientific worker to provide the greater productive powers or even more effective ways of protecting crops unless society has an economic and social organisation which provides the appropriate seeds, fertilisers, tools, etc., and cultivators capable of understanding their use. This presupposes some developed system of industry, transport, distribution, and education, in which the cultivator and the inventor can both be fostered. The immense complexity of modern pure and applied science requires a corresponding complex social organisation.

When, however, we turn from the sphere of production to that of commerce and distribution, we enter a world of crude empiricism, secrecy, and mystification into which scientific method or principles have yet to permeate, and exact knowledge and its free interchange is almost totally absent. Our distributive and economic system remains on the basis of a pre-scientific era, wholly unadjusted to the change, and unable to bear the burdens placed upon it by this problem of new and almost incredible abundance. Adjustment is called for and can only be effective when the spirit and methods of science are freely applied in this sphere also, and it is recognised that the new powers involve the release of the general human life from Nature's old exaction of drudgery for a mere pittance. The release into an enlarged and enriched leisure for all men for general human culture would appear to be the only alternative to chronic unemployment.

It is thus not machinery that is at fault but the abuse of the powers which machinery has given to mankind, through mistakes in the economic and political sphere. The application of scientific methods in the fields of distribution and finance has as yet scarcely been attempted or the problem resolved of how proper control is to be exercised over machinery in the face of vested interests, traditional outlook, organisation, and habits of thought better adapted to rillage industries than

$$
\text { No. 3279, VoL. 130] }
$$


to the far-flung factories and communications of the modern world. Machinery, the product of scientific knowledge, can only be controlled by greater knowledge, more widely understood and thoroughly applied. The mistakes in our economic, financial, and distributive systems can only be corrected by the application in these fields of the same scientific logic and strict submission to fact and impartial deduction which have given us the machines.

The contribution of science to these interwoven problems of leisure and distribution is not limited to the impartial examination of problems of finance and distribution. There are also required those qualities of mind which collectively make up the spirit of science-the readiness to face change or adopt new outlooks, theories, or hypotheses, the habits of accurate observation, collection, and arrangement of all relevant facts, the willingness to experiment, the power to formulate hypotheses and to use and test them as tools, not as creeds. These are qualities and habits which cannot be acquired or practised without sincerity of purpose, honesty of thought, and open-mindedness, and it is these, as well as the imagination which the scientific investigator must also possess, that are needed if we are to solve the problems of leisure and distribution. If it is true, as General Smuts pleads, that we need the cool, serious, gentle spirit of science in human affairs, and that the application of the true scientific spirit would make possible such a reign of justice and fair play on earth as only poets have dreamt of, it is also true that without the quality of imagination there can be no inspiring vision, no rising out of the common ruts of thought, either in science, in art, or in religion. The greatest men of science in every age have been men of vision possessed of imaginative powers which enabled their thoughts to pierce through the clouds of ignorance and uncertainty and discover some clue to the truth upon which their experimental genius and critical judgment could later be brought to bear.

There is much about us to suggest that the inspiration of such examples is one of the most important contributions that science can make to the solution of the common problems of humanity to-day. Not merely the technique of scientific method for ascertaining the relevant and undistorted facts upon which effective action must be based, not merely the spirit of adventure and the willingness to face change and to try new methods, essential as they are in the dynamic order of society which science has created, but also the vision of a new order of society in which man has quietly and confidently evolved the powers demanded of him for planning intelligently and co-operating effciently on an international scale in the utilisation of the abundant resources of the world. As Prof. L. P. Jacks recently reminded us, " a race which emerged from the ignorance and brutality of barbaric ages is quite capable of emerging from mechanisation and standardisation, and will emerge if brave men stand to it ".

Scientific methods offer us a surer hope of the solution of our modern problems than the financial, economic, or commercial considerations which have so long dictated policy. It would be unwise, however, to assert that science alone would be sufficient. Science can assist in the discovery of the right ways for the use of the new powers with which it has endowed mankind, but the endeavours of science to make the world a better place to live in and to help men to be worthier of the splendid possibilities of life will be largely defeated unless there can be brought to bear the moral power which ensures the rightful use of those new powers. To the scientific mind and energy which patiently and impartially sorts out the facts of life there must be joined a sense of values, a moral purpose, and a vision of order and beauty competent to compel action upon the ascertained facts for the ordered development of mankind.

Overshadowed by the financial and political events of last auturnn, the centenary meetings of the British Association did not receive their normal share of public attention, but the wise words of the presidential address may well come to be regarded as prophetic by many by whom at the time they were unheeded: "Among the human values thus created science ranks with art and religion. In its selfless pursuit of truth, in its vision of order and beauty, it partakes of the quality of both. More and more it is beginning to make a profound æsthetic and religious appeal to thinking people. ... One of the gravest tasks before the human race will be to link up science with ethical values and thus to remove grave dangers affecting our future. . . Science may be destined to become the most effective drive towards ethical values, and in that way to render its most priceless service." As the spiritual development of mankind comes once more in step with material progress, it will be possible for the combined moral, ethical, and scientific forces to build up a well-balanced civilisation from which disease, poverty, and war have been eliminated and men strive only to excel in the service they render, the contribution they offer to the common weal.

No. 3279, VoL. 130] 